\title{
Compression Load Tests on Composite Foundations of Spread Footing Anchored by Helical Anchors
}

\author{
Mingqiang Sheng $\mathbb{D}^{1},{ }^{1}$ Zengzhen Qian $\mathbb{D}^{1},{ }^{2}$ and Xianlong Lu $\mathbb{D D}^{3}$ \\ ${ }^{1}$ School of Civil Engineering and Architecture, Nanchang University, Nanchang 330031, China \\ ${ }^{2}$ School of Engineering and Technology, China University of Geosciences, Beijing 100083, China \\ ${ }^{3}$ China Electric Power Research Institute, Beijing 100192, China
}

Correspondence should be addressed to Zengzhen Qian; zzqian@cugb.edu.cn

Received 26 February 2021; Accepted 12 July 2021; Published 31 July 2021

Academic Editor: Haoyuan Hong

Copyright (c) 2021 Mingqiang Sheng et al. This is an open access article distributed under the Creative Commons Attribution License, which permits unrestricted use, distribution, and reproduction in any medium, provided the original work is properly cited.

\begin{abstract}
This study elucidates the compression behavior of a type of composite foundation of spread footing anchored by helical anchors. Three composite foundations were installed at a field site, and compression load testing was carried out on each foundation. Both the site conditions and the load tests were documented comprehensively. The compression load-settlement curves of composite foundations exhibit an initial linear-elastic segment, a curve transition, and a final linear region, and their capacities should be interpreted from the load-settlement curves. Five representative interpretation criteria (Chin, Terzaghi and Peck, slope tangent, tangent intersection, and $\mathrm{L}_{1}-\mathrm{L}_{2}$ ) were employed to determine the capacity of each foundation. Both the helical anchors and the footing share compression loadings on the composite foundation. Soil pressure cells at the center, near the edge, and at the corner of the footing represent a distribution from the lower, middle, and higher ranges of incremental soil pressures underneath the footing. Helical anchors underneath the footing approximately share $60 \%-80 \%$ of total load applied on the composite foundation pier, and higher compression resistance of a composite foundation can be obtained by increasing the footing embedment depth and the number of helical anchors underneath the footing.
\end{abstract}

\section{Introduction}

Spread footings have been widely designed to meet some unique soil conditions of geology and terrain such as in swampy grounds, flood plains, tropical areas, and thick residual deposits with reduced bearing capacities [1, 2]. Numerous investigations on the compression behavior of spread footings have been conducted based on theoretical and experimental analyses $[3,4]$. As found in many practical applications, spread foundations are economical than piles under certain circumstances [5]. However, the solution for foundation designs using spread footings directly on the soil with reduced bearing capacity may result in low admissible pressure associated with remarkable settlement [6], and the employing of piles may lead to an excessive increase in cost. An alternative for such instance is therefore the proposal recommended in this study by designing a type of composite foundation as shown in Figure 1, in which helical anchors are installed in the lower layer of soil and a spread footing at the top layer of soil will then be connected with these helical anchors. The helical anchors in such composite foundation can obtain instant load-carrying capacities upon installation and can be constructed through groundwater without casing, unaffected by caving soils.

Helical anchors have been recognized as a practical alternative to traditional pile foundations in construction industry because of their ease of installation and cost-effectiveness [7]. Experimental research findings have indicated that the performance of helical anchors under compressive and tensile loadings is similar, and the anchor plates can increase the anchor load-carrying capacity obviously, as does the underream in a underreamed cast-inplace pile [8]. Several design methods have been suggested to predict the helical pile load-carrying capacity under 


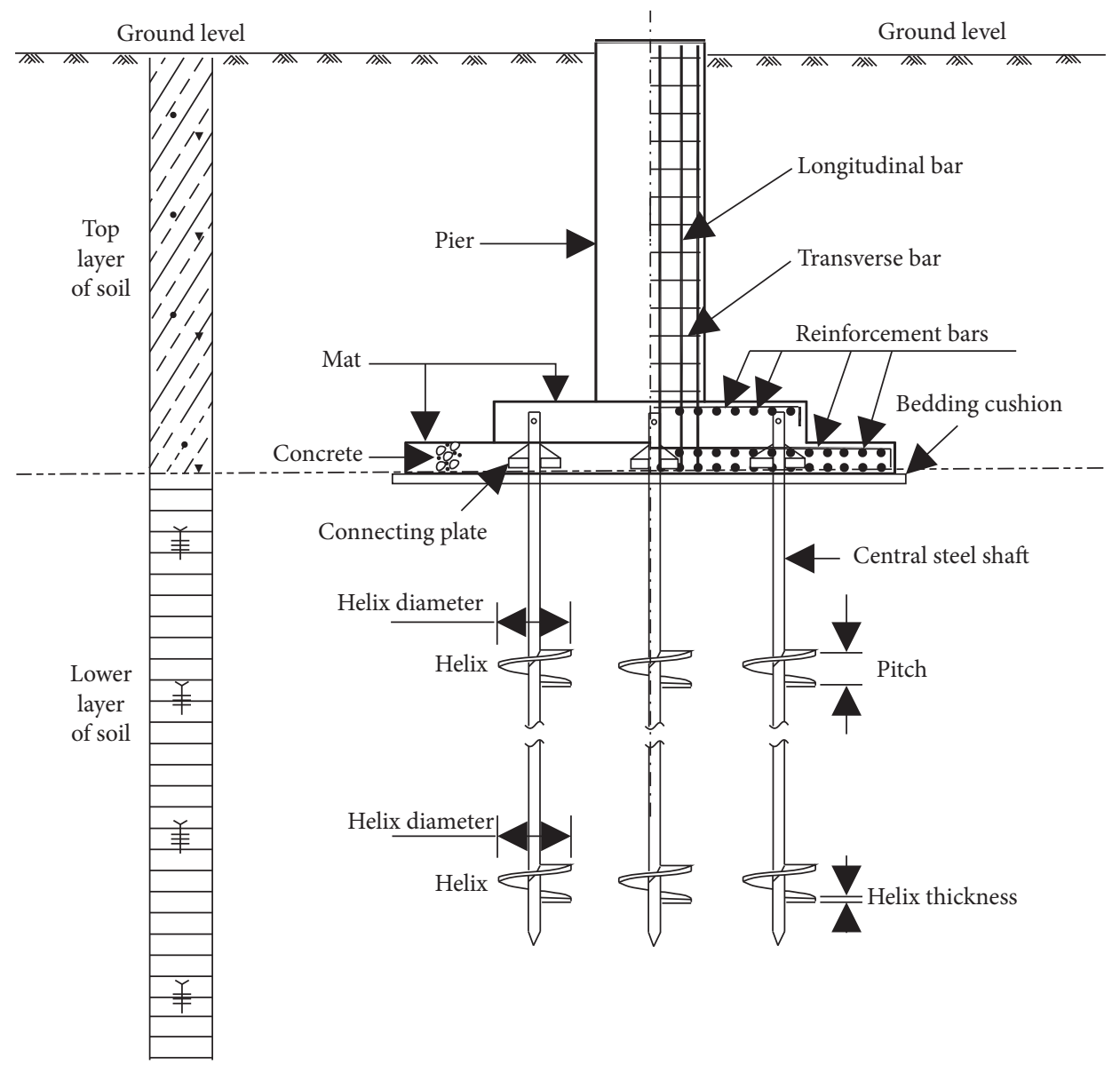

FIGURE 1: Design scheme of the composite foundation in this study.

compressive and tensile loads based on the individual plate anchor theories [9-14], whereas some methods are similar to those recommended for underreamed cast-in-place pile foundations [13, 15-17].

However, the composite foundation in Figure 1 makes the helical anchor-soil-footing interaction more complicated, and very insufficient experimental research findings are available for the justification of its design. This study has three objectives: (1) to examine the compression load-settlement behavior of the composite foundation as depicted in Figure 1; (2) to obtain the distribution of incremental soil pressures underneath the spread footing; and (3) to investigate the load-transfer mechanism when compression loads are applied to such composite foundation.

\section{Test Site Conditions}

The field test site is selected at Liaoyang City, Liaoning Province, China. From ground level to the foundation embedment depth in this study, the soil profile consists of a topsoil, silty clay, and sandy silt, categorized according to Chinese National Standard GB50007 [15]. Table 1 lists the detailed soil profile and properties at the testing site. Groundwater was not observed at the time that the test foundations were installed and tested.
As listed in Table 1, soil profile at the site comprises a surficial fill layer of sand and gravel mixed with some organics, which extends to about $1.0 \mathrm{~m}$ with SPT number ranging from 6 to 7 and moisture content ranging from 19\% to $25 \%$. Underlying this surficial layer is the soft plastic to plastic silty clay that extends to depths between $8.6 \mathrm{~m}$ and $8.8 \mathrm{~m}$ below ground surface with SPT number ranging from 9 to 23. Moisture content of this silty clay layer varies from $20 \%$ to $27 \%$, with an average of $25.9 \%$. Further down is a sandy clay with a thickness about $10 \mathrm{~m}$ with SPT number ranging from 33 to 48 .

To investigate the on-site soil properties, a plate static loading test was carried out with a concrete plate $(0.8 \mathrm{~m}$ in diameter and $0.55 \mathrm{~m}$ in height) on the silty clay at the depth of $1.5 \mathrm{~m}$ after topsoil was removed. Figure 2 demonstrates the load-settlement response from the plate loading test.

There is no peak load and asymptote value on the curve, and therefore, the maximum bearing capacity is difficult to determine from the test. There are two failure criteria generally recommended in China $[18,19]$ : (a) the load is held for $24 \mathrm{~h}$ but with the rate of increment settlement still exceeding $0.10 \mathrm{~mm} / \mathrm{h}$; and (b) the total settlement is greater than $10 \%$ of the diameter of the plate. The lesser of the loads corresponding to above two criteria is then defined as the failure load. The first criterion controlled the failure in this 
TABLE 1: Test site soil conditions.

\begin{tabular}{lcccc}
\hline Layer & Soil layer thickness $H(\mathrm{~m})$ & SPT number $N($ blow counts/300 mm) & $\begin{array}{c}\text { Moisture content } w \\
(\%)\end{array}$ & Unit weight $\gamma\left(\mathrm{kN} / \mathrm{m}^{3}\right)$ \\
\hline Topsoil (fill) & $0.9-1.0$ & $6-7$ & $19-25$ & - \\
Silty clay & $7.7-7.8$ & $9-23$ & $20-27$ & 18.9 \\
Sandy silt & $10.2-10.8$ & $33-48$ & - & 19.3 \\
\hline
\end{tabular}

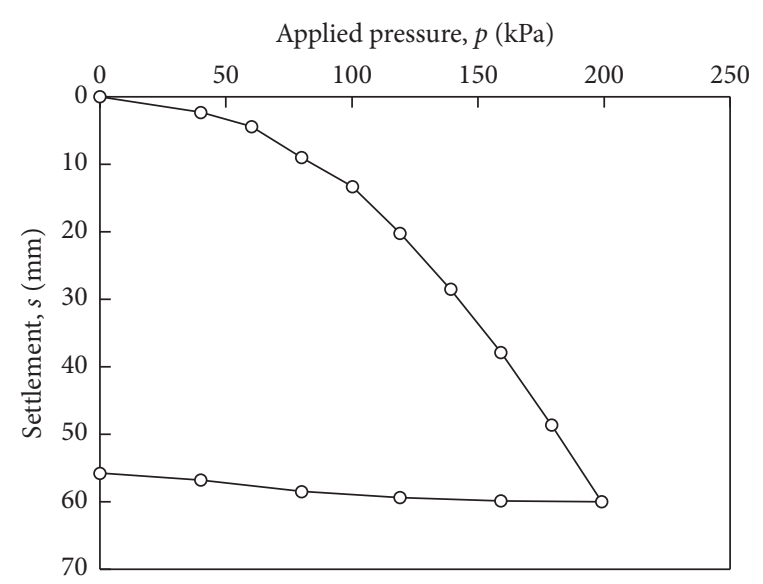

FIGURE 2: Load-settlement response in the plate loading test on silty clay at the depth of $1.5 \mathrm{~m}$.

study, and the determined bearing capacity was $175 \mathrm{kPa}$ with a settlement about $6 \%$ of the plate diameter.

\section{Foundation Installation}

Three composite foundations as shown in Figure 3, numbered from $\mathrm{CF} 1$ to $\mathrm{CF} 3$, were constructed and tested under compression load at the aforementioned site. As shown in Figure 3, all footings of the composite foundations in this study have two stepped mats, with upper mat having dimensions of length $/$ width $/$ thickness $=1.5 \mathrm{~m} / 1.5 \mathrm{~m} / 0.3 \mathrm{~m}$ compared to $2.1 \mathrm{~m} / 2.1 \mathrm{~m} / 0.3 \mathrm{~m}$ for the lower. The piers of the three footings have an identical cross section of $0.6 \mathrm{~m}$ by $0.6 \mathrm{~m}$. The helical anchors were manufactured from a single cylindrical steel shaft with three welded helices, which served as triple-helix piles in a composite foundation. The central cylindrical shafts were manufactured of steel pipes of $108 \mathrm{~mm}$ outer diameter and $10 \mathrm{~mm}$ wall thickness. All helices had a dimension of $0.5 \mathrm{~m}$ diameter, $0.01 \mathrm{~m}$ thickness, and $0.25 \mathrm{~m}$ pitch, and they were welded at intervals of center-to-center spacing of $1.2 \mathrm{~m}$ along the steel shaft.

As listed in Figure 3, three field compression load tests were conducted on: (i) CF1, the footing with embedment depth of $1.5 \mathrm{~m}$ anchored by a four-helical-anchor group in square arrangement with spacing $s_{p}=2.2 D$ (where $D$ is the helix diameter, and $D=0.5 \mathrm{~m}$ in this study) and $L=4.85 \mathrm{~m}$ (where $L$ is the central steel shaft length); (ii) CF2, the spread footing with embedment depth of $2.0 \mathrm{~m}$ anchored by a fourhelical-anchor group with $s_{p}=2.2 D$ and $L=4.85 \mathrm{~m}$; and (iii) CF3, the footing with embedment depth of $2.0 \mathrm{~m}$ anchored by a five-helical-anchor group, with four $4.85 \mathrm{~m}$ long helical anchors being placed in square arrangement at the four corners with $s_{p}=2.2 D$ and with a $3.85 \mathrm{~m}$ long helical anchor being placed at the core of the footing.

The construction of the composite foundations in Figure 3 was performed by three procedures. The first procedure was to excavate native topsoil to the designed footing embedment depth. Then, the second procedure was to install helical anchors in the excavated pit by screwing them into soil by trained operators with a special torque wrench equipment which had a safety link to prevent overtorquing of the anchors and to avoid damage to the anchors and loss of soil. The helixes advanced steadily at a rate of the pitch. Finally, the last procedure was to cast reinforced concrete pad and pier for footings, including the main progresses of binding steel bars, supporting wall framework, pouring concrete, removing template and maintenance, and backfilling soil.

All footings were made from sulfate-resistant concrete of nominally identical quality with a specified 28 -day compressive strength of $25 \mathrm{MPa}$. Figure 4 shows the installed helical anchors and the footing with reinforcement prior to concrete placement.

\section{Test Setup and Loading Procedure}

Each of the compression load tests on the composite foundations was conducted after the footing concrete had cured for about four weeks. The same axial compression loading test setup, instrumentation, and data measurement system were employed for all tests. The compression load was axially applied through a system comprising a loading platform, a reaction beam, and a hydraulic jack in line with the central longitudinal axis of the composite foundation.

During each load test, pier-head settlements of the composite foundation were measured at four points with a $90^{\circ}$ separation on the pier top head using four electronic displacement transducers with $50 \mathrm{~mm}$ range and $0.01 \mathrm{~mm}$ sensitivity. All the electronic displacement transducers were attached to the reference beams fixed over the pier head, and they were sufficiently stiff to sustain the instrumentation and to prevent excessive variations in the measurements.

Each compression load test was conducted using static monotonic loading with no unload-reload loops. The slowly maintained-load method was employed in all the tests; namely, the compression load was applied in increments of $10 \%$ of the predicted maximum resistance of each individual foundation, and the composite foundation was enabled to move under each maintained-load increment until a designated settlement rate was achieved. Each compression load increment was held after loading until two consecutive settlements within each hour were less than $0.10 \mathrm{~mm}$. The next load increment was subsequently added. It is noted in 

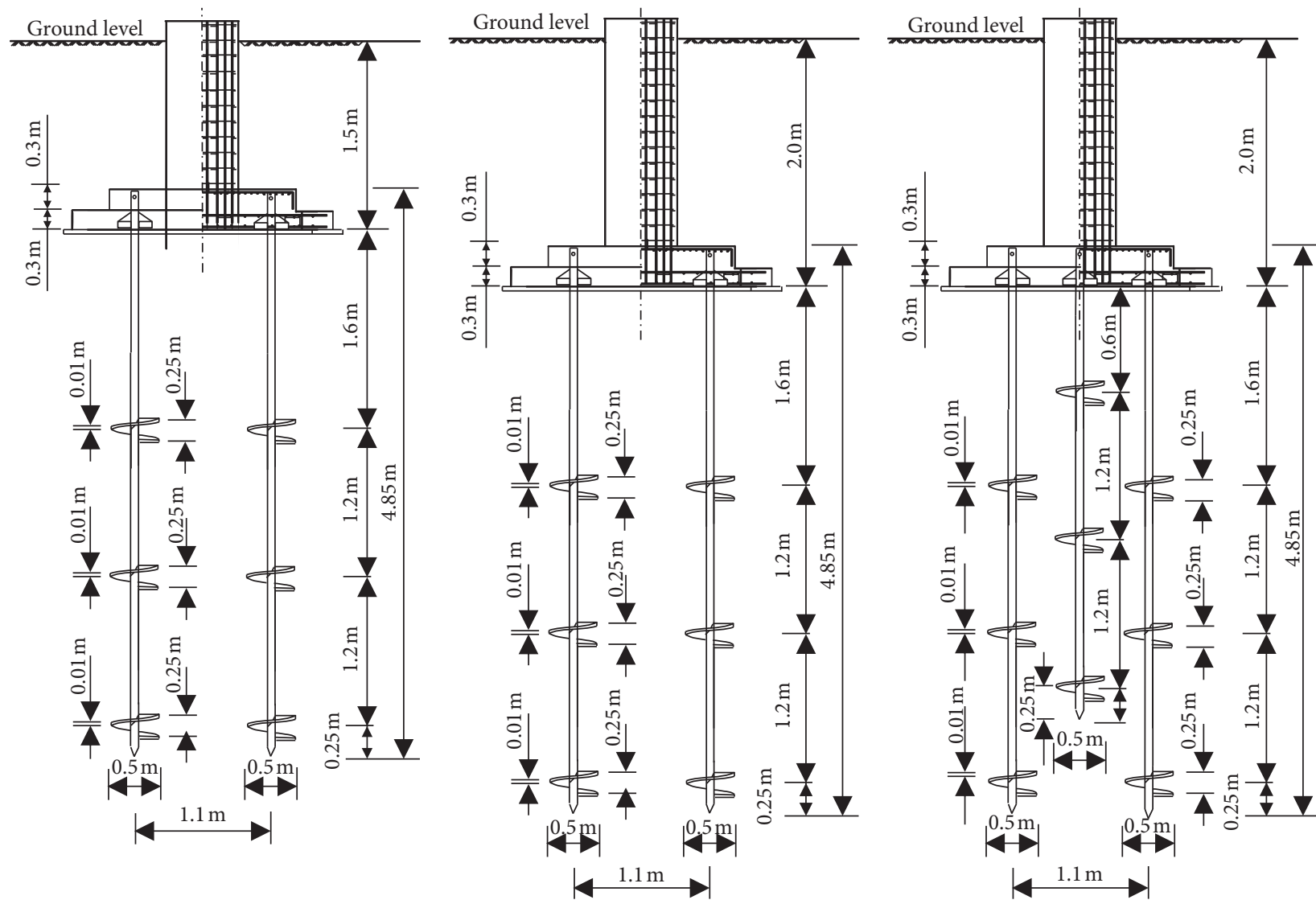

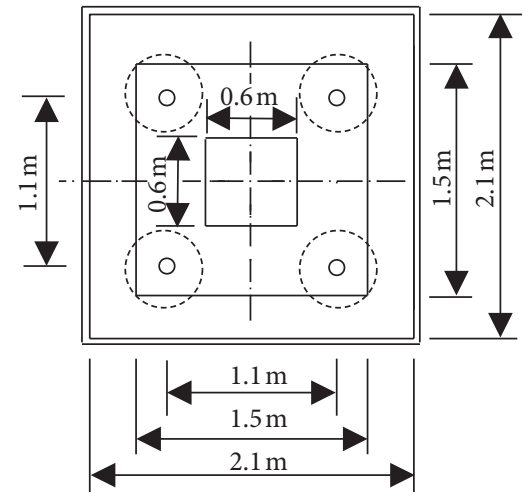

(a)

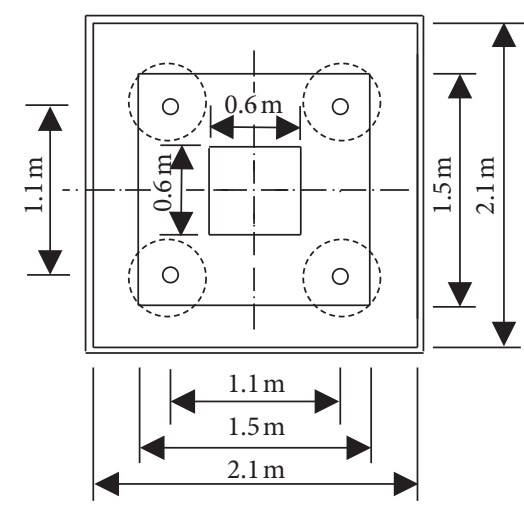

(b)

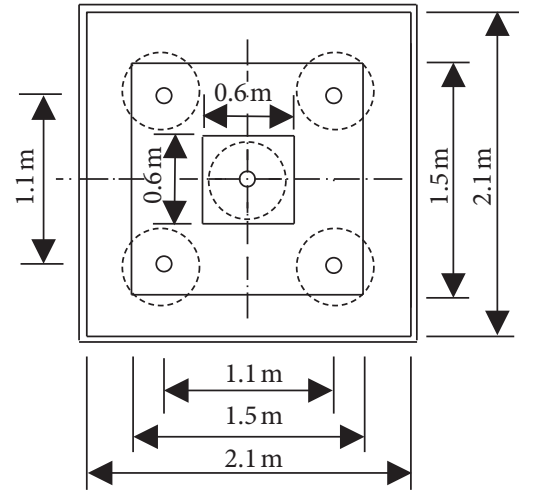

(c)

Figure 3: Details of composite foundations in the test: (a) CF1, (b) CF2, and (c) CF3.

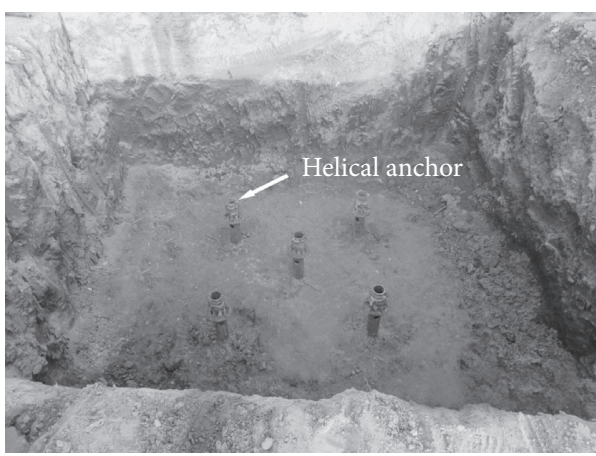

(a)

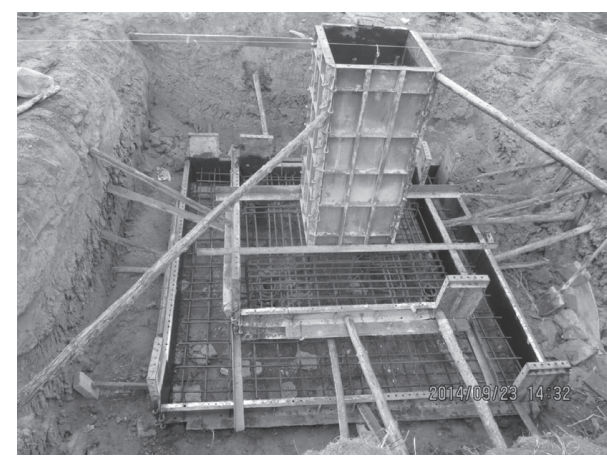

(b)

Figure 4: Photo of a composite foundation prior to concrete placement: (a) installed helical anchors and (b) the footing with reinforcement and supporting wall framework. 
this study that the two consecutive settlement values were defined as the average of the vertical pier-head displacements within each hour from the four electronic displacement transducers on the pier head of the composite foundation. It is the typical procedure recommended by Chinese National Code GB50007 [18] and Local Code JGJ 94 [19-22].

\section{Test Results and Discussion}

5.1. Load-Settlement Response and Load Capacity. In limit state design, it is of great importance to consider the ultimate limit state (ULS) (addressing foundation capacity) and the serviceability limit state (SLS) (addressing foundation settlement) simultaneously [23-25]. Therefore, the load test results in this study are first analysed in terms of the loadsettlement curves. Figure 5 shows the variation of compression load against pier-head vertical settlement for each composite foundation. It should be noted that the settlements in Figure 5 are the means of the output of the four electronic displacement transducers on the pier head.

It can clearly be seen that the compression load-settlement curves in Figure 5 are similar to those of drilled shafts $[26,27]$ and footings under compression loads [3], and they can generally be divided into three distinct segments: initial linear-elastic, curve transition, and final linear, as was suggested by Hirany and Kulhawy [28-30] in Figure 6. Various criteria have been recommended in the literature to interpret the failure load from this type of load-displacement curve. In this study, five criteria which employ varied interpretation bases, as noted in Table 2, were used to evaluate the capacity of each composite foundation. In general, these criteria can be considered as representative of existing criteria because they represent a distribution of interpreted failure loads from the lower, middle, and higher bounds, as identified in practice $[20,21]$. The interpreted failure loads of the test foundations, as well as the corresponding settlements, are listed in Table 3. It should be noted that $Q_{\mathrm{L} 1}$ is not an interpreted failure load, but the elastic limit, and it is listed for reference only.

Table 3 indicates that a significant scatter exists for the interpreted load capacities of the foundation using different criteria, and the interpreted failure loads vary from 475 to $1166 \mathrm{kN}$ for CF1, from 479 to $1410 \mathrm{kN}$ for CF2, and from 562 to $1435 \mathrm{kN}$ for CF3. The slope tangent, tangent intersection, and Terzaghi and Peck methods yield compression capacities less than the $\mathrm{L}_{1}-\mathrm{L}_{2}$ method and are therefore located within the curve transition segment between $\mathrm{L}_{1}$ and $\mathrm{L}_{2}$. However, the Chin method always yields the highest load capacity, even greater than the applied maximum load. Therefore, defining the failure load as $Q_{\text {CHIN }}$ yields a value that is too large, possibly because $Q_{\mathrm{CHIN}}$ is based on a hyperbolic mathematical model that corresponds to the asymptote of the load-settlement curve. In general, the $\mathrm{L}_{1}-\mathrm{L}_{2}$ method could interpret all the load tests, and therefore $Q_{\mathrm{L} 2}$ could be adopted as a base for comparison.

As shown in Table 3, the interpreted load capacity defined by $\mathrm{L}_{1}-\mathrm{L}_{2}$ method, $Q_{\mathrm{L} 2}$, is $910 \mathrm{kN}$ for CF2 and $813 \mathrm{kN}$ for CF1, with a corresponding settlement of $29.57 \mathrm{~mm}$ for

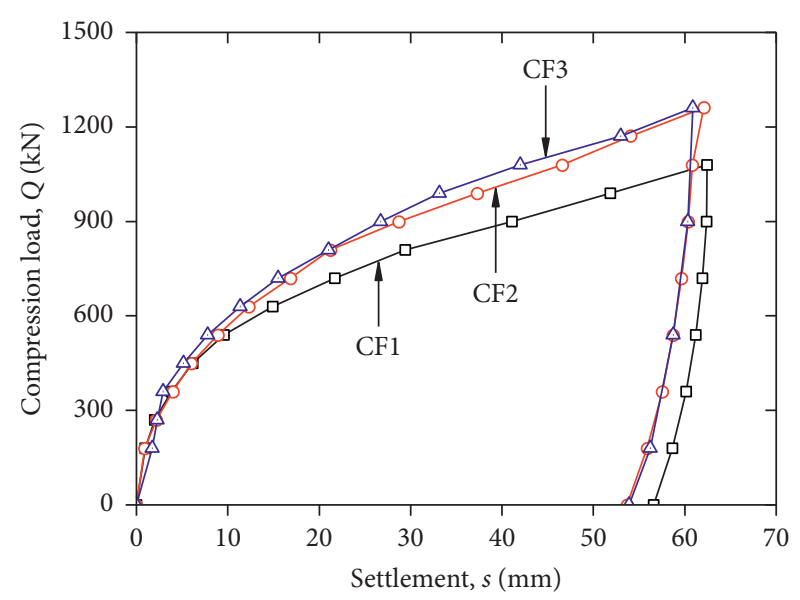

FIgURE 5: Variation of applied compression load against pier-head settlement.

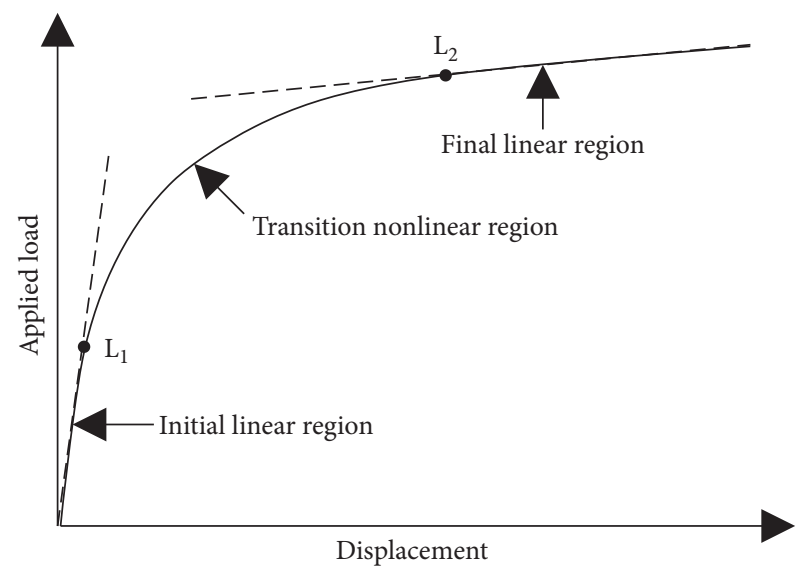

FIgure 6: Sections of load-displacement curve for the $\mathrm{L}_{1}-\mathrm{L}_{2}$ method [28-30].

CF2 and $30.22 \mathrm{~mm}$ for CF1. It can be seen that a $0.5 \mathrm{~m}$ increase of footing embedment depth for CF2 yields an increase of about $12 \%$ in the compression capacity. The interpreted load capacity, $Q_{\mathrm{L} 2}$, of $\mathrm{CF} 3$ is about $8 \%$ higher than that of CF2. This demonstrates that the compression capacity of a composite foundation as shown in Figure 1 depends on the dimension of footings and the layout of helical anchors. A higher compression load resistance can be obtained by increasing the footing embedment depth and the number of helical anchors underneath spread footing.

5.2. Soil Pressures underneath the Footing. When a composite foundation is subjected to compression loads, the steelreinforced concrete footing may behave as a rigid body, and therefore, the soil underneath the footing becomes significant to resist the compression forces. To obtain a better understanding of the load-transfer mechanism, as illustrated in Figure 7, fifteen miniature vibrating-wire soil pressure cells, with a diameter of $0.10 \mathrm{~m}$ and a capacity of $500 \mathrm{kPa}$, were fixed underneath each footing of the composite 
TABle 2: Definitions of representative interpretation criteria examined in this study.

\begin{tabular}{|c|c|c|}
\hline Method & Category & Definition of interpreted capacity, $Q$ \\
\hline Chin method [31] & $\begin{array}{l}\text { Mathematical } \\
\text { modeling }\end{array}$ & $\begin{array}{l}Q_{\mathrm{CHIN}} \text { is equal to the inverse slope, } 1 / \mathrm{m} \text {, of the line, } s / Q=\mathrm{m} s+c \text {, where } Q \text { is the load, } s \text { is } \\
\text { the total displacement and } m \text { and } c \text { are the slope and intercept of the line, respectively. }\end{array}$ \\
\hline Terzaghi and Peck method & $\begin{array}{l}\text { Displacement } \\
\text { limitation }\end{array}$ & $(25.4 \mathrm{~mm})$ total displacement. \\
\hline Slope tangent method [33] & $\begin{array}{l}\text { Graphical } \\
\text { construction }\end{array}$ & $\begin{array}{l}Q_{\mathrm{ST}} \text { occurs at a displacement equal to the initial slope of the load-displacement curve } \\
\text { plus } 0.15 \text { inch }(3.8 \mathrm{~mm}) .\end{array}$ \\
\hline $\begin{array}{l}\text { Tangent intersection } \\
\text { method }[34,35]\end{array}$ & $\begin{array}{l}\text { Graphical } \\
\text { construction }\end{array}$ & $\begin{array}{l}Q_{\mathrm{TI}} \text { is determined as the intersection of two lines drawn as tangents to the initial linear } \\
\text { and final linear portions of the load-displacement curve and projected to the load- } \\
\text { displacement curve. }\end{array}$ \\
\hline $\mathrm{L}_{1}-\mathrm{L}_{2}$ method $[28-30]$ & $\begin{array}{l}\text { Graphical } \\
\text { construction }\end{array}$ & $\begin{array}{c}Q_{\mathrm{L} 1} \text { and } Q_{\mathrm{L} 2} \text { correspond to elastic limit and failure threshold loads, respectively, as } \\
\text { shown in Figure } 6 .\end{array}$ \\
\hline
\end{tabular}

TABLE 3: Interpreted compression load capacities and settlements for all three foundations.

\begin{tabular}{lccccccccccc}
\hline \multirow{2}{*}{ Foundation number } & \multicolumn{8}{c}{ Interpreted compression capacity, $Q^{\mathrm{a}}(\mathrm{kN})$, and the settlement, $s^{\mathrm{b}, \mathrm{c}}(\mathrm{mm})$} \\
& $\mathrm{Q}_{\mathrm{L} 1}$ & $s_{\mathrm{L} 1}$ & $\mathrm{Q}_{\mathrm{ST}}$ & $s_{\mathrm{ST}}$ & $\mathrm{Q}_{\mathrm{TI}}$ & $s_{\mathrm{TI}}$ & $\mathrm{Q}_{\mathrm{L} 2}$ & $s_{\mathrm{L} 2}$ & $Q_{\mathrm{T} \& \mathrm{P}}$ & $Q_{\mathrm{CHIN}}$ & $s_{\mathrm{CHIN}}$ \\
\hline CF1 & 214 & 1.26 & 475 & 7.21 & 632 & 15.10 & 813 & 30.22 & 764 & 1166 & $>62.43^{\mathrm{d}}$ \\
CF2 & 205 & 1.15 & 479 & 6.88 & 642 & 12.93 & 910 & 29.57 & 858 & 1410 & $>62.05$ \\
CF3 & 375 & 3.20 & 562 & 8.51 & 724 & 15.53 & 977 & 32.12 & 878 & 1435 & $>60.90$ \\
\hline
\end{tabular}

${ }^{a}$ Interpreted load capacities for various methods: $Q_{\mathrm{ST}}$, slope tangent method; $Q_{\mathrm{TI}}$, tangent intersection method; $Q_{\mathrm{L} 1}, \mathrm{~L}_{1}$ method; $Q_{\mathrm{L} 2}, \mathrm{~L}_{2}$ method; $Q_{\mathrm{T} \& \mathrm{P}}$, Terzaghi and Peck method; and $Q_{\mathrm{CHIN}}$, Chin method. ' ${ }^{\mathrm{b}} \mathrm{Settlements} \mathrm{for} \mathrm{the} \mathrm{various} \mathrm{methods:} s_{\mathrm{ST}}$, slope tangent method; $s_{\mathrm{TI}}$, tangent intersection method; $s_{\mathrm{L} 1}$, $\mathrm{L}_{1}$ method; $s_{\mathrm{L} 2}, \mathrm{~L}_{2}$ method; $s_{\mathrm{T} \& \mathrm{P}}$, Terzaghi and Peck method; and $s_{\mathrm{CHIN}}$, Chin method. ${ }^{\mathrm{c} B y}$ definition, $s_{\mathrm{T} \& \mathrm{P}}=25.4 \mathrm{~mm}$, not included in the table. ${ }^{\mathrm{d}}$ The symbol $(>)$ expresses that the interpreted settlement is greater than the measured data.

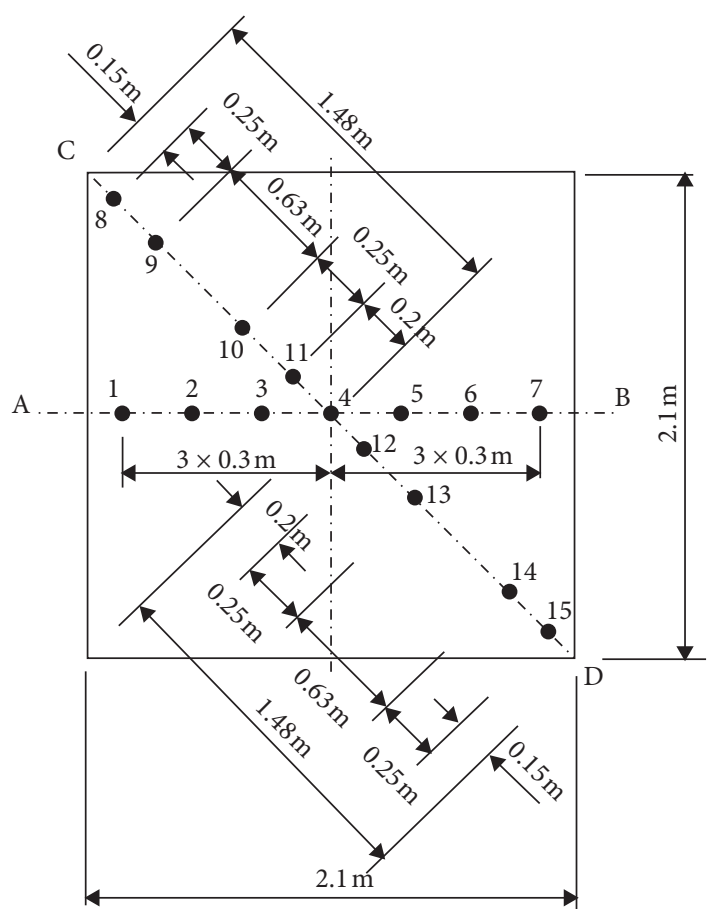

(a)

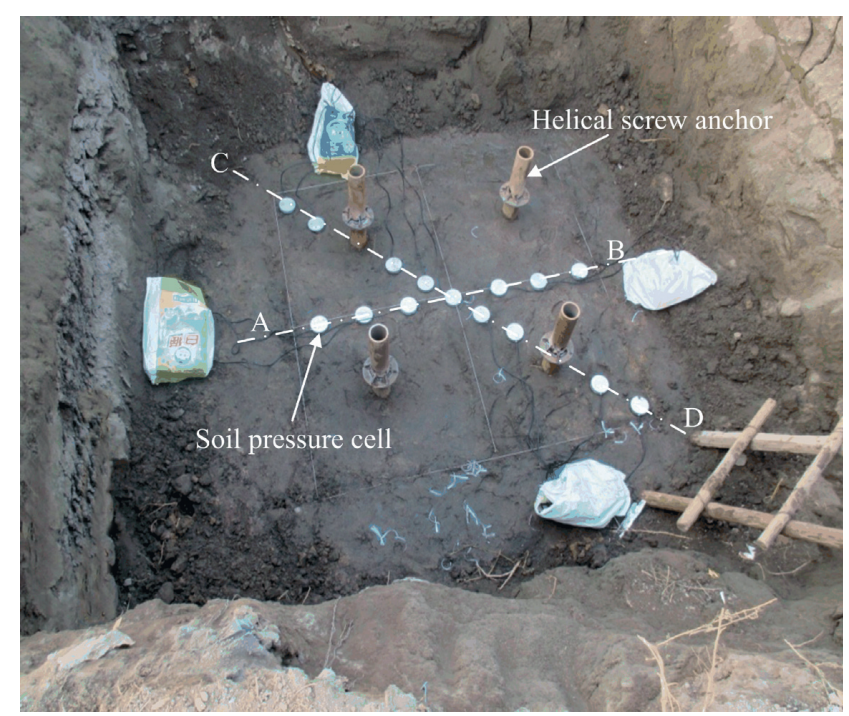

(b)

FIGURE 7: Details for (a) schematic diagram and (b) photograph of the arrangement of soil pressure cells.

foundations after completion of the first two procedures during the installation.

As demonstrated in Figure 7, the soil pressure cells were arranged along the center line $\mathrm{AB}$ and diagonal line $\mathrm{CD}$ and they were numbered 1 to 7 and 8 to 15 in sections $A B$ and $\mathrm{CD}$, respectively. All the soil pressure cells were calibrated and fixed within a $50 \mathrm{~mm}$ thick sand layer. Unfortunately, the soil pressure cell 4 of CF3 was damaged after installation. 

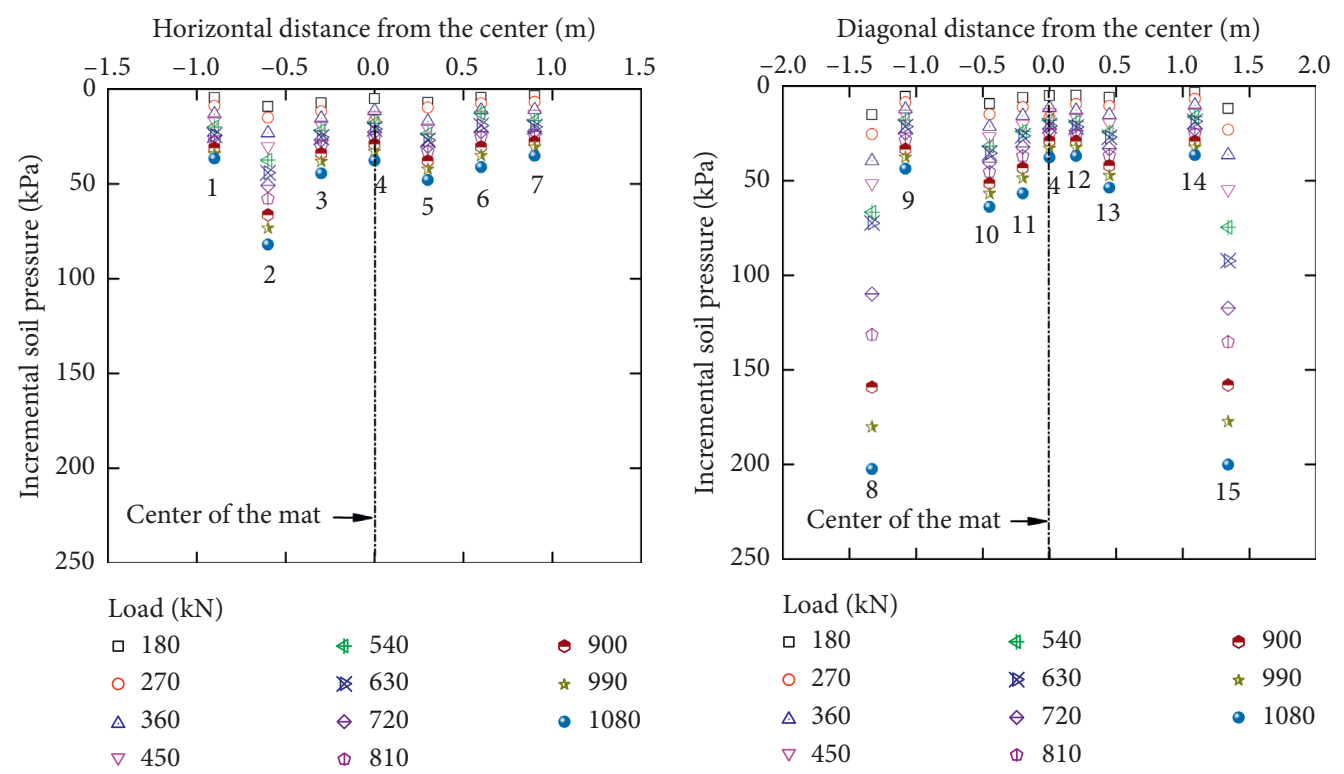

(a)
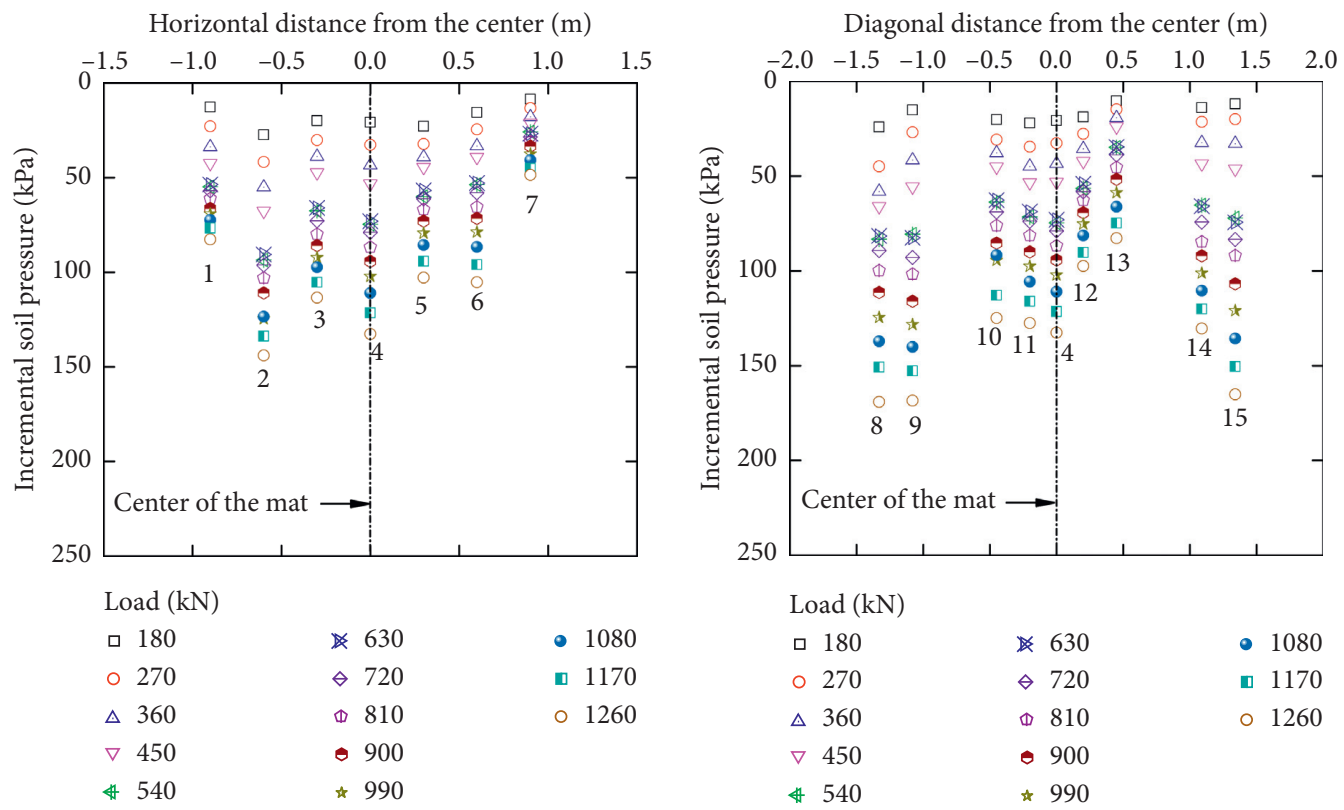

(b)

FIgURE 8: Continued. 

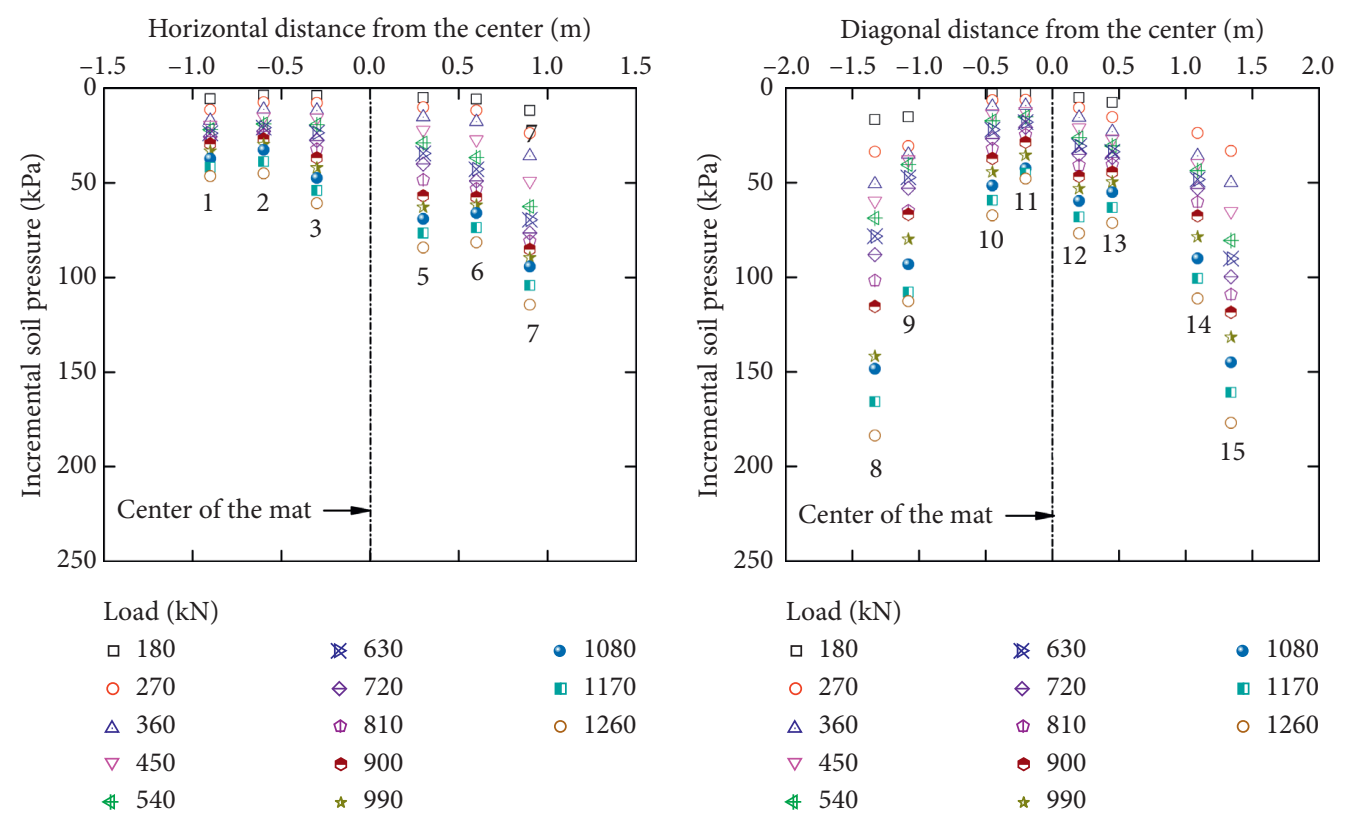

(c)

Figure 8: Distribution of incremental soil pressures underneath the footing during compression load testing for (a) CF1, (b) CF2, and (c) CF3.

TABLe 4: Average soil pressures and compression resistances from footing and helical anchors.

\begin{tabular}{|c|c|c|c|c|c|c|c|c|c|}
\hline \multirow[t]{2}{*}{ Applied load on footing pier head $(\mathrm{kN})$} & \multicolumn{3}{|c|}{$\begin{array}{c}\text { Average soil pressure } \\
\text { underneath footing }(\mathrm{kPa})\end{array}$} & \multicolumn{3}{|c|}{$\begin{array}{l}\text { Compression resistance } \\
\text { from footing }(\mathrm{kN})\end{array}$} & \multicolumn{3}{|c|}{$\begin{array}{c}\text { Percentage of } \\
\text { compression resistance } \\
\text { from helical anchors (\%) }\end{array}$} \\
\hline & CF1 & $\mathrm{CF} 2$ & $\mathrm{CF} 3$ & CF1 & CF2 & $\mathrm{CF} 3$ & $\mathrm{CF} 1$ & $\mathrm{CF} 2$ & CF3 \\
\hline 180 & 6.6 & 17.7 & 7.0 & 29 & 78 & 31 & 83.8 & 56.6 & 83.0 \\
\hline 270 & 11.8 & 28.0 & 14.0 & 52 & 123 & 62 & 80.8 & 54.3 & 77.2 \\
\hline 360 & 16.7 & 37.7 & 21.0 & 74 & 166 & 93 & 79.5 & 53.8 & 74.3 \\
\hline 450 & 21.3 & 46.1 & 26.8 & 94 & 203 & 118 & 79.1 & 54.8 & 73.8 \\
\hline 540 & 26.2 & 54.9 & 32.5 & 115 & 242 & 144 & 78.6 & 55.7 & 73.4 \\
\hline 630 & 30.3 & 63.0 & 37.0 & 134 & 278 & 163 & 78.8 & 55.9 & 74.1 \\
\hline 720 & 36.7 & 68.9 & 41.4 & 162 & 304 & 183 & 77.5 & 57.8 & 74.6 \\
\hline 810 & 41.9 & 75.9 & 46.4 & 185 & 335 & 205 & 77.2 & 58.7 & 74.7 \\
\hline 900 & 48.7 & 83.8 & 51.3 & 215 & 370 & 226 & 76.2 & 58.9 & 74.8 \\
\hline 990 & 54.6 & 92.3 & 58.0 & 241 & 407 & 256 & 75.7 & 58.9 & 74.2 \\
\hline 1080 & 61.9 & 99.0 & 64.7 & 273 & 437 & 285 & 74.7 & 59.6 & 73.6 \\
\hline 1170 & - & 109.4 & 72.9 & - & 482 & 321 & - & 58.8 & 72.5 \\
\hline 1260 & - & 119.7 & 81.1 & - & 528 & 358 & - & 58.1 & 71.6 \\
\hline
\end{tabular}

The measured results of the fifteen soil pressure cells along horizontal center line $\mathrm{AB}$ and the diagonal line CD for CF1, $\mathrm{CF} 2$, and CF3 are plotted in Figure 8.

Figure 8 indicates that the incremental soil pressures underneath the footing gradually increase with increasing of the applied compression loads, and a similar trend can be observed for distribution of the incremental soil pressures. Soil pressure cells at the center, near the edge, and at the corner represent a distribution from the lower, middle, and higher ranges of the incremental soil pressures underneath the footing. This phenomenon is similar to that of a foundation underpinned by micropiles reported by Han and Shu [36].
5.3. Percentage of Loads on Helical Anchors and Footing. The distribution of incremental soil pressures underneath the footing in Figure 8 indicates that the helical anchors and the footing of the composite foundation both share the compression loads. As expected, a well-designed composite foundation to resist compression loadings will rely on how much of the compression resistance comes from the helical anchors and how much of that comes from the soil beneath the footing.

Based on the principle that the compression load applied on the composite foundation can be shared by the helical anchors and the soil beneath the footing, the compression resistance of the footing for each of composite foundations was estimated by the measured incremental soil pressures of the soil 


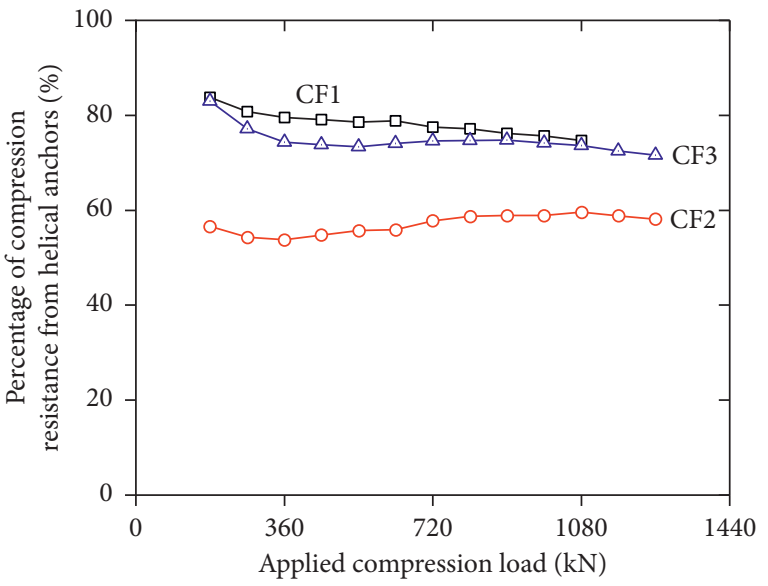

FIGURE 9: Variation in percentage of compression resistance from the helical anchors underneath footing.

pressure cells underneath the footing. As listed in Table 4, the average soil pressure underneath the footing corresponding to each compression load increment is calculated by each individual soil pressure cell. Then, the compression resistance from the footing is determined by using this average soil pressure to multiply the footing area. Finally, the corresponding compression resistance from the helical anchors can be obtained. For the purpose of analysis, as tabulated in Table 4, the compression resistance from helical anchors corresponding to each load increment is expressed as the percentage of the applied load on the composite foundation pier. Figure 9 shows the variation in the percentage of the compression resistance from the helical anchors for $\mathrm{CF} 1, \mathrm{CF} 2$, and CF3.

As shown in Figure 9, the percentage of the compression resistance from helical anchors during the loading fluctuates between $74.7 \%$ and $83.8 \%$ for CF1, between $53.8 \%$ and $59.6 \%$ for CF2, and between $72.5 \%$ and $83.0 \%$ for CF3. In general, the percentage tends to slightly decrease with the increase of the total load applied on the composite foundation pier. This reduction of the load on the helical anchors demonstrated that the screw anchors had started to yield, and more compression load was transferred onto the soil underneath the footing. The helical anchors carry approximately $60 \%-80 \%$ of the applied compression loads; in other words, the helical anchors share more loads than the footing.

\section{Conclusions}

Three axial compression load tests were carried out on a type of composite foundation of spread footing anchored by helical anchors. Based on the field load test results, the following conclusions can be reached:

(1) The compression load-settlement responses of composite foundations approximately exhibit three distinct segments: initial linear-elastic, curve transition, and final linear, which are similar to those of drilled shafts and footings under compression loads, and their compression resistances should be interpreted employing an appropriate criterion as done in other studies.
(2) Of the five representative interpretation criteria (Chin, Terzaghi and Peck, slope tangent, tangent intersection, and $\mathrm{L}_{1}-\mathrm{L}_{2}$ ) examined in this study, the slope tangent, tangent intersection, and Terzaghi and Peck methods are located within curve transition segment of the load-settlement curve, whereas the Chin method yields the highest load capacity, even greater than the measured data. According to $\mathrm{L}_{1}-\mathrm{L}_{2}$ method, $\mathrm{L}_{1}$ is a definition for the elastic limit, while $\mathrm{L}_{2}$ could be a useful definition for the interpreted load capacity and could be adopted as a base for comparison.

(3) Under compression loads, the helical anchors and the footing both share the applied compression loadings on the composite foundation. However, the helical anchors generally share more compression loads than the footing, approximately $60 \%-80 \%$ of the applied loads. Higher compression resistance of a composite foundation can be obtained by increasing the footing embedment depth and the number of helical anchors underneath the footing.

(4) When a composite foundation is subjected to compression loads, soil pressure cells at the center, near the edge, and at the corner represent a distribution from the lower, middle, and higher ranges of the incremental soil pressures underneath the footing. More load can be transferred onto the soils underneath the footing after the screw anchors start to yield.

(5) It should be noted that the results shown in this study are general behaviors applicable for the composite foundations of spread footing anchored by helical anchors installed in silty clay and sandy silt only, and any extrapolation of these results to other different soil foundations is not recommended.

\section{Data Availability}

The data used to support the findings of this study can be obtained from the corresponding author upon request. 


\section{Conflicts of Interest}

The authors declare that they have no conflicts of interest regarding the publication of this paper.

\section{Acknowledgments}

The authors gratefully acknowledge the financial support of the National Natural Science Foundation of China (52069013).

\section{References}

[1] J. C. Huffman and A. W. Stuedlein, "Reliability-based serviceability limit state design of spread footings on aggregate pier reinforced clay," Journal of Geotechnical and Geoenvironmental Engineering, vol. 140, no. 10, Article ID 04014055, 2014.

[2] J. C. Huffman, A. W. Strahler, and A. W. Stuedlein, "Reliability-based serviceability limit state design for immediate settlement of spread footings on clay," Soils and Foundations, vol. 55, no. 4, pp. 798-812, 2015.

[3] S. O. Akbas and F. H. Kulhawy, "Axial compression of footings in cohesionless soils. I: load-settlement behavior," Journal of Geotechnical and Geoenvironmental Engineering, vol. 135, no. 11, pp. 1562-1574, 2009.

[4] E. G. Diaz-Segura, "Assessment of the range of variation of $\mathrm{N} \gamma$ from 60 estimation methods for footings on sand," Canadian Geotechnical Journal, vol. 50, no. 7, pp. 793-800, 2013.

[5] J.-L. Briaud, "Spread footings in sand: load settlement curve approach," Journal of Geotechnical and Geoenvironmental Engineering, vol. 133, no. 8, pp. 905-920, 2007.

[6] N. C. Consoli, M. A. Vendruscolo, and P. D. M. Prietto, "Behavior of plate load tests on soil layers improved with cement and fiber," Journal of Geotechnical and Geoenvironmental Engineering, vol. 129, no. 1, pp. 96-101, 2003.

[7] M. Elkasabgy and M. H. El Naggar, "Axial compressive response of large-capacity helical and driven steel piles in cohesive soil," Canadian Geotechnical Journal, vol. 52, no. 2, pp. 224-243, 2015.

[8] S. N. Rao, Y. V. S. N. Prasad, and M. D. Shetty, "The behaviour of model screw piles in cohesive soils," Soils and Foundations, vol. 31, no. 2, pp. 35-50, 1991.

[9] J. I. Adams and D. C. Hayes, "The uplift capacity of shallow foundations," Ontario Hydro Research Quarterly, vol. 19, pp. 1-13, 1967.

[10] G. G. Meyerhof and J. I. Adams, "The ultimate uplift capacity of foundations," Canadian Geotechnical Journal, vol. 5, no. 4, pp. 225-244, 1968.

[11] M. P. Mitsch and S. P. Clemence, "Uplift capacity of helix anchors in sand," in Proceedings Of ASCE Convention, Uplift Behavior Of Anchor Foundations In Soil, pp. 26-47, ASCE, Detroit, Michigan, USA, October 1985.

[12] J. S. Mooney, S. J. Adamczak, and S. P. Clemence, "Uplift capacity of helix anchors in clay and silt," in Proceedings Of ASCE Convention, Uplift Behavior Of Anchor Foundations In Soil, pp. 48-72, ASCE, Detroit, Michigan, USA, October 1985.

[13] Z. H. Elsherbiny and M. H. El Naggar, "Axial compressive capacity of helical piles from field tests and numerical study," Canadian Geotechnical Journal, vol. 50, no. 12, pp. 1191-1203, 2013.

[14] K. Gavin, P. Doherty, and A. Tolooiyan, "Field investigation of the axial resistance of helical piles in dense sand," Canadian Geotechnical Journal, vol. 51, no. 11, pp. 1343-1354, 2014.
[15] S. N. Rao, Y. V. S. N. Prasad, and C. Veeresh, "Behaviour of embedded model screw anchors in soft clays," Géotechnique, vol. 43, no. 4, pp. 605-614, 1993.

[16] R. S. Merifield, "Ultimate uplift capacity of multiplate helical type anchors in clay," Journal of Geotechnical and Geoenvironmental Engineering, vol. 137, no. 7, pp. 704-716, 2011.

[17] D. Wang, R. S. Merifield, and C. Gaudin, "Uplift behaviour of helical anchors in clay," Canadian Geotechnical Journal, vol. 50, no. 6, pp. 575-584, 2013.

[18] CNS GB 50007, "Code for Design of Building Foundations" Chinese National Standard, China Architecture and Building Press, Beijing, China, 2011.

[19] CLC JGJ 94, "Technical Code for Building Pile Foundations" Chinese Local Standard, China Architecture and Building Press, Beijing, China, 2008.

[20] Z. Z. Qian, X. L. Lu, and W. Z. Yang, "Axial uplift behavior of drilled shafts in Gobi gravel," Geotechnical Testing Journal, vol. 37, no. 2, pp. 205-217, 2014.

[21] Z.-Z. Qian, X.-L. Lu, X. Han, and R.-M. Tong, "Interpretation of uplift load tests on belled piers in Gobi gravel," Canadian Geotechnical Journal, vol. 52, no. 7, pp. 992-998, 2015.

[22] X. L. Lu, Z. Z. Qian, and W. Z. Yang, "Axial uplift behavior of belled piers in sloping ground," Geotechnical Testing Journal, vol. 40, no. 4, pp. 579-590, 2017.

[23] K. K. Phoon and F. H. Kulhawy, Serviceability Limit State Reliability-Based Design" Chapter 9, Reliability-Based Design in Geotechnical Engineering: Computations and Applications, pp. 344-384, CRC Press, Florida, US, 2008.

[24] M. Dithinde, K. K. Phoon, M. De Wet, and J. V. Retief, "Characterization of model uncertainty in the static pile design formula," Journal of Geotechnical and Geoenvironmental Engineering, vol. 137, no. 1, pp. 70-85, 2011.

[25] X. L. Lu, Z. Z. Qian, W. F. Zheng, and W. Z. Yang, "Characterization and uncertainty of uplift load-displacement behaviour of belled piers," Geomechanics and Engineering International Journal, vol. 11, no. 2, pp. 211-234, 2016.

[26] Y.-J. Chen and Y.-C. Fang, "Critical evaluation of compression interpretation criteria for drilled shafts," Journal of Geotechnical and Geoenvironmental Engineering, vol. 135, no. 8, pp. 1056-1069, 2009.

[27] M. C. M. Marcos, Y.-J. Chen, and F. H. Kulhawy, "Evaluation of compression load test interpretation criteria for driven precast concrete pile capacity," KSCE Journal of Civil Engineering, vol. 17, no. 5, pp. 1008-1022, 2013.

[28] A. Hirany and F. H. Kulhawy, "Conduct And Interpretation of Load Tests on Drilled Shaft Foundations: Detailed Guidelines," Report No. EL-5915, Electric Power Res. Inst., Palo Alto, California, US, 1988.

[29] A. Hirany and F. H. Kulhawy, "Interpretation of Load Tests on Drilled Shafts. II: Axial Uplift" Proc., Foundation Engineering: Current Principles and Practices, F. H. Kulhawy, Ed., pp. 1150-1159, ASCE, New York, US, 1989.

[30] A. Hirany and F. H. Kulhawy, "On the interpretation of drilled foundation load test results," in Proceedings of International Deep Foundations Congress, M. W. O'Neill and F. C. Townsend, Eds., pp. 1018-1028, ASCE, Orlando, Florida, February 2002.

[31] F. K. Chin, "Estimation of the ultimate load of piles not carried to failure," in Proceedings Of the 2nd Southeast Asian Conference On Soil Engineering, pp. 81-90, Singapore, June 1970.

[32] K. Terzaghi and R. B. Peck, Soil Mechanics in Engineering Practice, Wiley, New York, US, 2nd Ed. edition, 1967. 
[33] T. D. O'Rourke and F. H. Kulhawy, "Observations on Load Tests on Drilled Shafts" Proc., Drilled Piers and Caissons II, C. N. Baker, Ed., pp. 113-128, ASCE, New York, US, 1985.

[34] W. S. Housel, "Pile load capacity: estimates and test results," Journal of the Soil Mechanics and Foundations Division, vol. 92, no. 4, pp. 1-30, 2002.

[35] M. J. Tomlinson, Pile Design and Construction Practice (A Viewpoint publication), Cement \& Concrete Association of Great Britain, London, UK, 1977.

[36] J. Han and S.-L. Ye, "A field study on the behavior of a foundation underpinned by micropiles," Canadian Geotechnical Journal, vol. 43, no. 1, pp. 30-42, 2006. 